\title{
Comparison of an ELISA assay for the detection of adhesive/invasive Neospora caninum tachyzoites
}

Comparação de um ensaio de ELISA para a detecção de taquizoítas adesivos/invasivos de Neospora caninum Luiz Miguel Pereira ${ }^{1,2}$; Ana Patrícia Yatsuda ${ }^{1,2 *}$

${ }^{1}$ Faculdade de Ciências Farmacêuticas de Ribeirão Preto, Universidade de São Paulo - USP, Ribeirão Preto, SP, Brasil

${ }^{2}$ Núcleo de Apoio à Pesquisa em Produtos Naturais e Sintéticos, Universidade de São Paulo - USP, Ribeirão Preto, SP, Brasil

Received August 06, 2013

Accepted January 15, 2014

\begin{abstract}
Neospora caninum belongs to the phylum Apicomplexa, the causative agent of neosporosis, which leads to economic impacts on cattle production. A common feature among apicomplexan parasites is the invasive process driven mostly by the parasite. As a first evaluation of candidate molecules that play a possible role by interfering in this invasive process, the in vitro invasion assay is a fast and direct way to screen future agonists or antagonists. This work involved the development of a new cell culture ELISA and transient $\beta$-galactosidase activity applied to the semi-quantitative detection of $N$. caninum in Vero cell culture. Cell culture ELISA is based on histochemistry and immunology, resulting in a colorimetric reaction. The $\beta$-galactosidase activity was obtained by the transient transfection of the lac $Z$ gene under control of RPS13 promoter of $N$. caninum. These methods were used to evaluate the effects of temperature $\left(37^{\circ} \mathrm{C}\right.$ and $85^{\circ} \mathrm{C}$ ) on the invasion and adhesion of tachyzoites. The three tested methods (real time PCR, $\beta$-galactosidase activity and ELISA) showed a similar pattern, indicating that different methods may be complementary.
\end{abstract}

Keywords: Neospora caninum, cell culture ELISA, LacZ gene, transfection, real-time PCR, invasion assay.

\section{Resumo}

Neospora caninum, parasita do filo Apicomplexa, é causador da neosporose, doença responsável por perdas econômicas importantes na pecuária. Um fator comum entre os apicomplexas é o processo de invasão majoritariamente dirigido pelo parasita. Dentre as primeiras avaliaçóes de moléculas candidatas, que possivelmente interferem no processo de invasão, o ensaio de invasáo in vitro é um meio rápido e direto de selecionar futuros agonistas ou antagonistas. Este trabalho desenvolveu um novo ELISA baseado em cultura (Cell-culture ELISA) e um ensaio que mede a atividade transiente de $\beta$-galactosidase, aplicados para a detecçáo semiquantitativa de $N$. caninum em células Vero. Cell-culture ELISA é baseado em histoquímica e imunologia, resultando em uma reação colorimétrica. A atividade da $\beta$-galactosidase foi obtida pela transfecção transiente do gene LacZ sob controle do promotor RPS13 de $N$. caninum. Esses métodos avaliaram os efeitos da temperatura $\left(37^{\circ} \mathrm{C}\right.$ e $85^{\circ} \mathrm{C}$ ) sobre a invasão e adesão. Os três métodos testados (real time PCR, atividade de $\beta$-galactosidase e ELISA) mostraram um padrão similar, indicando que diferentes métodos podem ser complementares. Adicionalmente, esse ELISA é adequado para aplicação em laboratórios carentes de uma complexa estrutura para métodos de detecçấo moleculares.

Palavras-chave: Neospora caninum, cell-culture ELISA, gene LacZ, transfecção, PCR em tempo real, ensaio de invasão.

\section{Introduction}

Neospora caninum is an apicomplexan protozoan first isolated in 1988 by Dubey and coworkers when they investigated the origin of a severe neuromuscular disorder in dogs (DUBEY et al., 1988). Infected cows represent economic losses due to fetal

\footnotetext{
${ }^{*}$ Corresponding author: Ana Patrícia Yatsuda

Departamento de Análises Clínicas, Bromatológicas e Toxicológicas, Faculdade de Ciências Farmacêuticas de Ribeiráo Preto, Universidade de Sáo Paulo - USP, CEP 14040-903, Ribeirão Preto, SP, Brasil

e-mail: ayatsuda@fcfrp.usp.br

Financial support: CAPES, CNPq, FAPESP.
}

abortion, stillbirth, clinical and subclinical disease, impaired milk production, neonatal deaths, reduced fertility and reduced value of infected cows (CORBELLINI et al., 2006). The losses resulting from neosporosis have recently been estimated to exceed US $\$ 1.3$ billion, affecting predominantly dairy cattle (REICHEL et al., 2013). Like any member of the phylum Apicomplexa, $N$. caninum is an obligatory intracellular parasite that invades the host cells by a conserved mechanism. Invasion of the host cell by the parasite occurs mainly through an active process, unlike the entry pathway of invasive bacteria (CESBRON- 
DELAUW et al., 2008). The infectious stage of Apicomplexa invades through a multifactorial process driven basically by the protein release of organelles called micronemes, rhoptries, and dense granules (MORAHAN et al., 2009). The direct or indirect detection of $N$. caninum, in vivo or in vitro, can be accomplished by several methods that include PCR and/or real-time PCR (BELL; RANFORD-CARTWRIGHT, 2002; DARWICH et al., 2012; HUGHES et al., 2006; MORENO et al., 2012), $\beta$-galactosidase (HOWE et al., 1997) and ELISA (JENKINS et al., 2002). Real-time PCR in $N$. caninum research using primers for the N5 genomic region of $N$. caninum (GenBank accession no. X84238) is widely applied as a quantitative method due to its fidelity and sensitivity (COLLANTES-FERNANDEZ et al., 2002; GHALMI et al., 2008; NAGULESWARAN et al., 2003). N. caninum expressing $\beta$-galactosidase is a useful tool to detect tachyzoite integrity in secretion assays (LOVETT et al., 2000; PEREIRA et al., 2011), especially when stored as a stable cytoplasmic enzyme (HOWE et al., 1997). The reproducible and stable reaction with CPRG is well established and widely applied in several microorganisms and cell lineages (D'ANGELO et al., 2009; ESPERANDIM et al., 2010; VAVROVA et al., 2010). The enzyme-linked immunoassay (ELISA) has proven to be a useful technique for antibody detection against a variety of antigens, since it enables rapid determination and antibody titration, making it very suitable for serological surveys (BJORKMAN; LUNDEN, 1998). There are several ELISA methodologies for the detection of $N$. caninum antibodies, based on either whole or fixed $N$. caninum tachyzoites, aqueous or detergent-soluble tachyzoite extracts, tachyzoite antigens incorporated into iscoms (immunostimulating complexes) or recombinant tachyzoite antigens (JENKINS et al., 2002).

All these immunoenzymatic techniques have been used for diagnosis, but none of them for measuring the invasion of $N$. caninum. This work introduces a modified ELISA, based on a Vero cell culture, as a semi-quantitative assay to detect adhesive and/ or invasive tachyzoites after an invasion assay. Unlike the existing ELISAs, this assay is based on histochemistry and immunology, allowing for the relative mensuration of invasion by means of a colorimetric reaction. This new method offers a direct and low cost route for detecting $N$. caninum after invasion assays, without steps such as protein or DNA extraction and purification. In addition to real time PCR, for comparison, $N$. caninum expressing $\beta$-galactosidase was obtained after transient transfection with a LacZ gene vector controlled by the RPS13 promoter of $N$. caninum. This paper reports the use of $N$. caninum promoters for heterologous expression, since most other studies have employed $T$. gondii promoters. The adhesion and/or invasion pattern of $N$. caninum, as well as the different effects of incubation temperature and time, were analyzed by different methods. In addition, the ELISA and $\beta$-galactosidase assays proved to be suitable alternatives to real-time PCR as screening methods for evaluating the effects of drugs on the $N$. caninum invasion process.

\section{Materials and Methods}

\section{Tissue culture and parasite purification}

$N$. caninum Nc-1 isolate was cultivated in Vero cell cultures maintained in RPMI-1640 medium (Sigma) supplemented with
$5 \%$ fetal calf serum, $2.05 \mathrm{mM}$ glutamine, $50 \mathrm{U}$ of penicillin/ streptomycin at $37^{\circ} \mathrm{C}$, and $5 \% \mathrm{CO}$ in $\mathrm{T}-25 \mathrm{~cm}^{2}$ and $75 \mathrm{~cm}^{2}$ tissue culture flasks (for $N$. caninum culture) or on 24 and 96-well culture plates (for invasion assay). The purification of tachyzoites was performed by exclusion chromatography in Sephadex G-25 (PD-10 columns, GE). The recovered parasites were counted in a Neubauer chamber after adequate dilution; the average recovery from a $25 \mathrm{~cm}^{2}$ flask culture was $2 \times 10^{7}$ tachyzoites.

\section{Evaluation of $N$. caninum viability by flow cytometry}

Freshly purified $N$. caninum tachyzoites $\left(1 \times 10^{6}\right.$ in $250 \mu \mathrm{l}$ PBS) incubated at $37^{\circ} \mathrm{C}$ for $1 \mathrm{~h}$ or $85^{\circ} \mathrm{C}$ for $20 \mathrm{~min}$ were evaluated by flow cytometry (FACSCanto, BD Biosciences) with an argon laser set to $488 \mathrm{~nm}$, and evaluated using FACSDiva BD 6.1.3 software. The gate corresponding to $N$. caninum characteristics was drawn by forward (size, FSC) and side scattering (complexity, SSC). Tachyzoite viability was evaluated by the incorporation of propidium iodide (20 ng/ $\mu$ l, Santa Cruz Biotechnology), with excitation at $535 \mathrm{~nm}$ and detection at $617 \mathrm{~nm}$. The percentage of live and dead (negative and positive to propidium iodide, respectively) tachyzoites was determined.

\section{Invasion assays}

All the invasion assays were performed according to the following protocol. Briefly, three concentrations of $N$. caninum tachyzoites $\left(3.5 \times 10^{6}, 1.75 \times 10^{6}\right.$ and $3.5 \times 10^{5}$ for ELISA and $\beta$-galactosidase, or $3.5 \times 10^{5}, 1.75 \times 10^{5}$ and $3.5 \times 10^{4}$ for realtime PCR) were diluted in $650 \mu \mathrm{l}$ RPMI. Tachyzoites were treated differently: i) applied immediately after purification, ii) $37^{\circ} \mathrm{C}$ for $1 \mathrm{~h}$, or iii) $85^{\circ} \mathrm{C}$ for $20 \mathrm{~min}$. These suspensions $(650 \mu \mathrm{l})$ were divided into three parts $(200 \mu \mathrm{l}$ each) and applied to Vero cells cultured in 96-well (ELISA) or 24-well plates ( $\beta$-galactosidase or real-time PCR). The tachyzoites were allowed to invade for $2 \mathrm{~h}$ at $37^{\circ} \mathrm{C}$, after which each well was washed three times with PBS and subjected to the three specific detection methods: ELISA, $\beta$-galactosidase and real-time PCR.

\section{Detection of $N$. caninum by ELISA}

The 96-well plates (TPP) were fixed with 3\% formamide in PBS for 15 min, permeabilized with PBS/0.2\% Triton X-100 for 30 min, washed once with PBS, and incubated with blocking buffer solution (2\% BSA, $50 \mathrm{mM}$ glycine in PBS) for $16 \mathrm{~h}$ at $4^{\circ} \mathrm{C}$. After washing with $\mathrm{PBS}$, antiserum against $N$. caninum (anti-Nc tachyzoite protein extract, 1:1000 (PEREIRA et al., 2011)) was incubated for $1 \mathrm{~h}$, followed by three washes in PBS. The secondary antibody goat anti-rabbit-peroxidase conjugate (1:10000, ZyMed-Invitrogen) was incubated for $1 \mathrm{~h}$ and then washed three times. The wells were incubated for $15 \mathrm{~min}$ with a TMB solution (ZyMed-Invitrogen). The blank was composed of the same antiserum but incubated in Vero cells, since the anti-Nc tachyzoite protein extract was raised against protein extract of $N$. caninum that had been cultivated in Vero cells, thus eliminating the response against these cells after the subtraction of Vero absorbance. The reaction was stopped with a $2 \mathrm{M} \mathrm{HCl}$ 
solution and measured at $450 \mathrm{~nm}$ (ELISA reader, SpectraMax Plus, Molecular Devices). These assays were performed in triplicate.

\section{Construction of $\beta$-galactosidase vector}

$N$. caninum expressing $\beta$-galactosidase was obtained via the transient insertion of the NcRPS13 subIV23LacZ plasmid. This vector was obtained after replacing the Toxoplasma gondii promoter region of RPS13 ((TgRPS13 with 1353bp from TgRPS13subIV23LacZ (van POPPEL et al., 2006)) with the homologous region from $N$. caninum (NcRPS13) (Figure 1). Primers with HindIII and NruI restriction sites were designed to amplify a region of $663 \mathrm{bp}$ upstream of the $N$. caninum RPS13 ORF. This fragment was linked to TgRPS13subIV23LacZ, which was pretreated with HindIII and NruI, generating NcRPS13subIV23LacZ. The $\beta$-galactosidase activity was evaluated (data not shown). The tetO region is a site with affinity for the TetR protein, which, once bound to the tet $\mathrm{O}$ site, blocks expression and is released from the site by tetracycline. This system is based on the E. coli tetracycline operon, which has been adapted for T. gondii and Plasmodium falciparum (DAS et al., 2011; MEISSNER et al., 2001, 2002; van POPPEL et al., 2006). However, only the $\beta$-galactosidase expression was employed in this study.

\section{Transfection of $N$. caninum for $\beta$-galactosidase expression}

Freshly purified tachyzoites $\left(5 \times 10^{7}\right)$ were resuspended with $25 \mu \mathrm{g}$ of NcRPS13 subIV23LacZ in cytomix buffer $(120 \mathrm{mM} \mathrm{KCl}$, $0.15 \mathrm{mM} \mathrm{CaCl}, 10 \mathrm{mM} \mathrm{K} \mathrm{HPO}_{4} / \mathrm{KH}_{2} \mathrm{PO}_{4}, 25 \mathrm{mM}$ HEPES, $2 \mathrm{mM}$ EDTA, and $5 \mathrm{mM} \mathrm{MgCl}_{2}, \mathrm{pH} 7.6$ ) supplemented with $5 \mathrm{mM}$ glutathione and stored on ice. Cells were transferred to a $0.4 \mathrm{~cm}$ gap cuvette (in ice) and electroporated at $1.8 \mathrm{kV}, 25 \mu \mathrm{Fd}$ and $100 \Omega$ in a BioRad GenePulser Xcell system. The electroporated cells were incubated in Vero cells cultured $\left(75 \mathrm{~cm}^{2}\right.$ flask, TPP) in incomplete RPMI (without fetal bovine serum) until total lysis of host cells occurred. The tachyzoites were purified by exclusion chromatography in Sephadex G-25 (PD-10 columns, GE) under the same conditions as the wild tachyzoites (see 2.1).

\section{Detection of $N$. caninum by $\beta$-galactosidase}

Adhesive/invasive $N$. caninum were incubated in lysis buffer (4-(2-hydroxyethyl)-1-piperazine ethanesulfonic acid, $100 \mathrm{mM}$

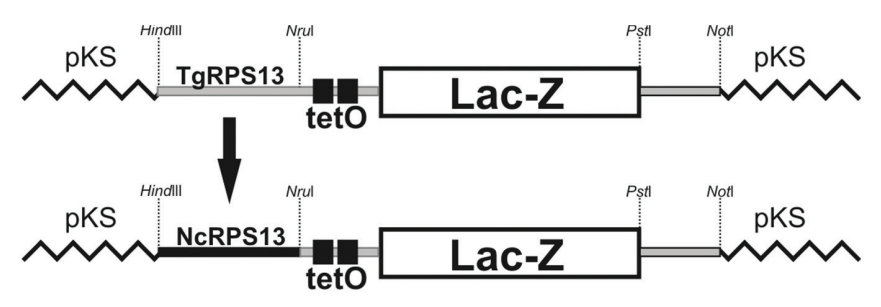

Figure 1. NcRPS13subIV23LacZ vector. The promoter region of the RPS13 gene from $N$. caninum (NcRPS13) was ligated (flanked by Hindll and Nrul) to control the expression of LacZ, replacing the original promoter TgRPS13 ( $T$. gondii) of vector TgRPS13subIV23LacZ from van Poppel et al. (2006).
HEPES, $1 \mathrm{mM} \mathrm{MgSO}$, 1\% Triton X-100, 5 mM Dithiothreitol, DTT, $\mathrm{pH} 8.0$ ) at $50^{\circ} \mathrm{C}$ for $1 \mathrm{~h}$. The lysate was centrifuged at $10,000 \mathrm{~g}$ at $4^{\circ} \mathrm{C}$ for $10 \mathrm{~min}$ and $20 \mu \mathrm{l}$ of supernatant was solubilized in $190 \mu \mathrm{l}$ of buffer lysis with $40 \mu \mathrm{l}$ of $6 \mathrm{mM}$ CPRG (chlorophenol red- $\beta$-D-galactopyranoside, Roche). The reaction was measured at $570 \mathrm{~nm}$ after $18 \mathrm{~h}$ at $37^{\circ} \mathrm{C}$ (ELISA reader, SpectraMax Plus, Molecular Devices). The invasion assays were performed in triplicate and the lac $Z$ activity in each well was evaluated in duplicate (final $n=6$ ).

\section{Detection of $N$. caninum by real-time PCR}

$N$. caninum DNA was extracted and purified from each well according to the manufacturer's instructions (Wizard SV Genomic DNA Purification System, Promega). Parasites were quantified by real-time PCR, using Nc 5 primers with the forward primer linked to FAM fluorophore Lux (Invitrogen) (PEREIRA et al., 2011). The experiment was carried out in a Mastercycler ep RealPlex (Eppendorf) and the results analyzed using RealPlex software (Eppendorf). As external standards, DNA corresponding to 1 to $10^{5} \mathrm{~N}$. caninum tachyzoites was used for the standard curve and the samples were calculated by interpolation from this standard curve. The invasion assay was performed in triplicate and the real-time reaction in duplicate for each well $(n=6)$.

\section{Statistical analyses}

The results of invasion assays were expressed as mean \pm standard deviation and analysis of variance (ANOVA) was employed for the dilutions and for $37^{\circ} \mathrm{C} /$ fresh and $85 / 37^{\circ} \mathrm{C}$ relations using the Tukey test, considering statistical significance at a level below $5 \%$. The overall analyses of dilutions were performed by linear regression and the $\mathrm{r}^{2}$ values were calculated. The analyses were performed using the Graph Pad PRISM 4.0 (Graph Pad, USA) statistical program.

\section{Results}

\section{Evaluation of liveldead N. caninum by flow cytometry}

The percentage of live parasites was determined to corroborate the invasion assays, confirming that the decrease in invasion capacity after incubation was due to the infeasibility of tachyzoites. This assay was also useful for detecting dead parasites that maintained their adhesive function. The gate representing size (forward scatter, axis $\mathrm{x}$ ) and granularity (side scatter, axis y) of the $N$. caninum tachyzoites treated at different temperatures (Figures 2A, B, C-1) was delimited and the groups were separated according to their fluorescence emission for live and dead tachyzoites after propidium iodide treatment. The rate of live parasites was $81.9 \%$ for freshly purified organisms, and $76.5 \%$ for $37^{\circ} \mathrm{C}$ and $1.5 \%$ for $85^{\circ} \mathrm{C}$ incubated parasites (Figures 2A, B, C-2). 
Freshly purified $N$. caninum
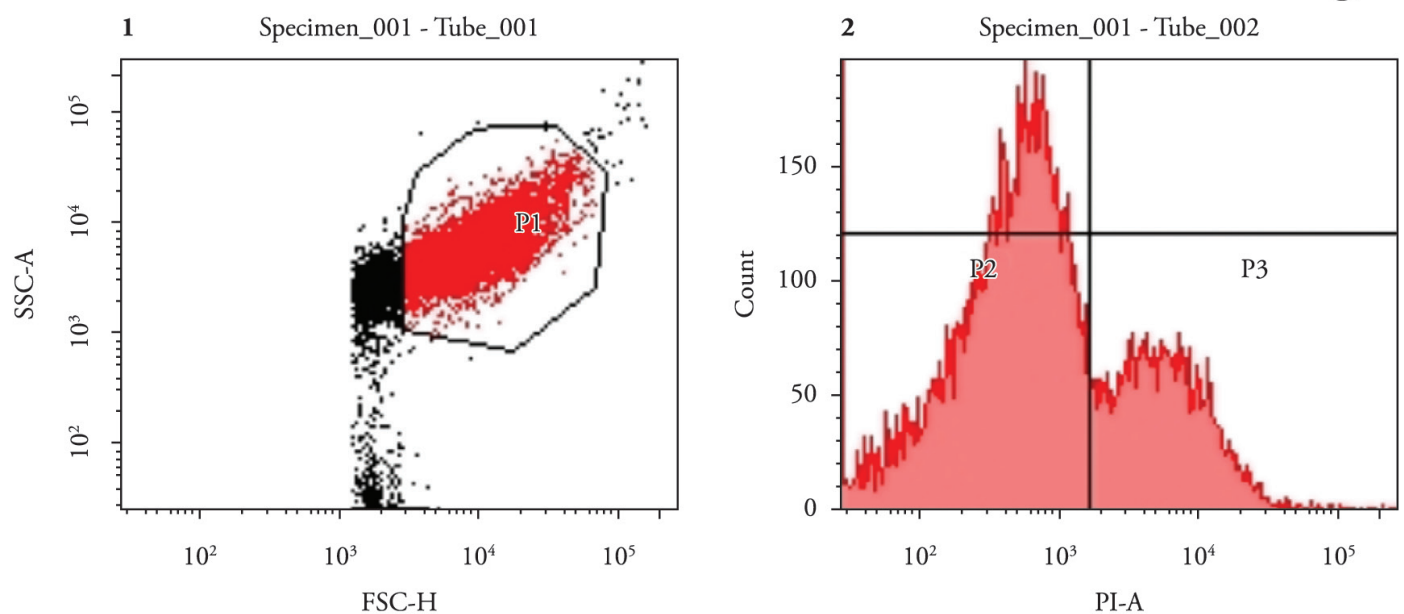

$37^{\circ} \mathrm{C}$ incubated $N$. caninum
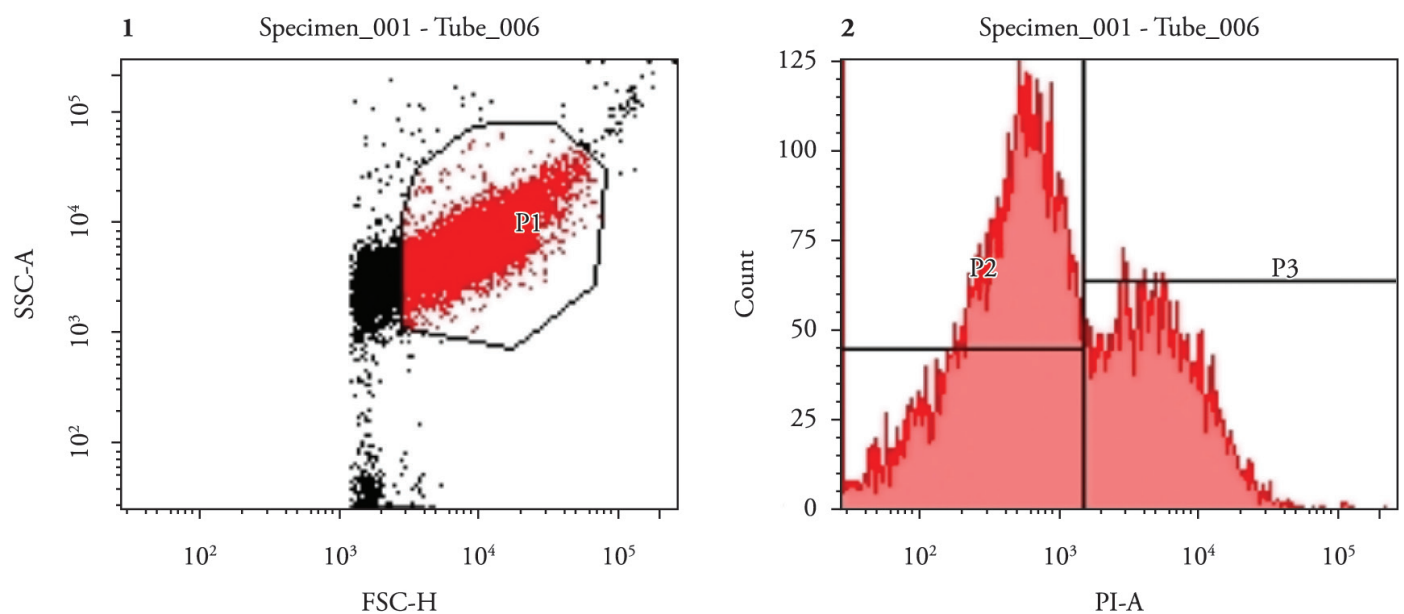

$85^{\circ} \mathrm{C}$ incubated $N$. caninum
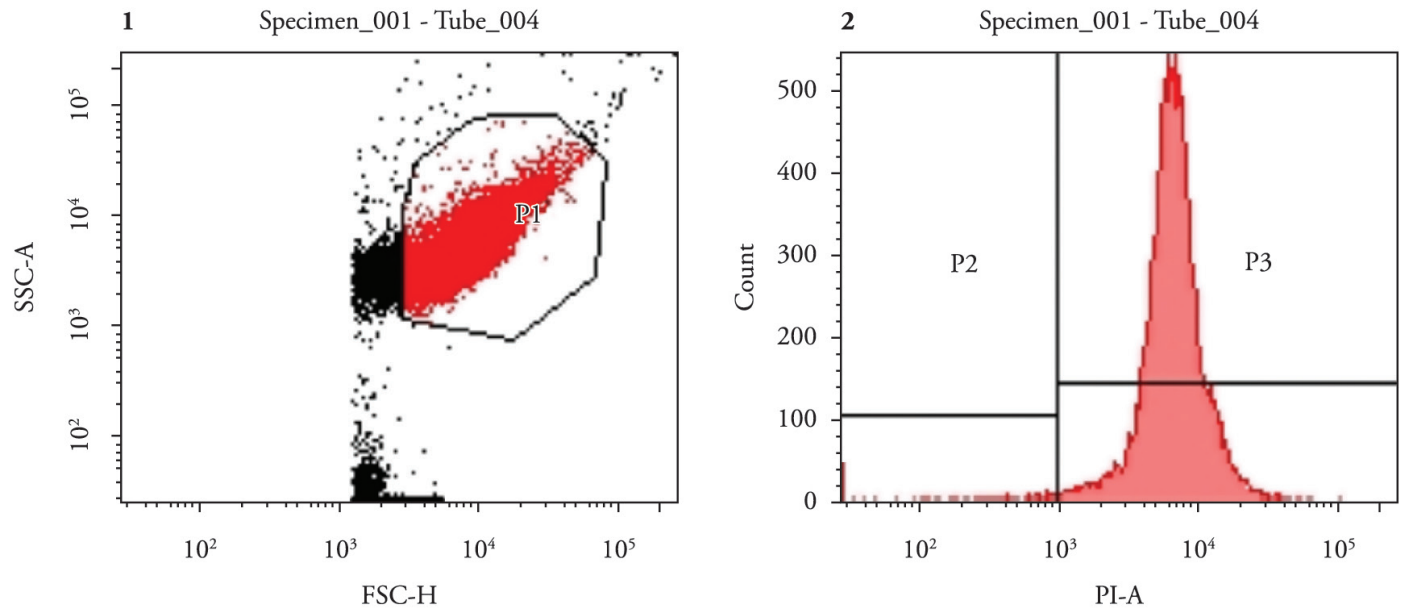

Figure 2. Evaluation of tachyzoite mortality with flow cytometry after different temperature treatments. Tachyzoites $\left(1 \times 10^{6}\right)$ incubated at $37^{\circ} \mathrm{C}, 85^{\circ} \mathrm{C}$ or freshly purified were mixed with propidium iodide (PI, $\left.20 \mathrm{ng} / \mu \mathrm{l}\right)$ and immediately analysed by flow cytometry. Cytograms $1 \mathrm{~A}, 1 \mathrm{~B}$ and $1 \mathrm{C}$ plot forward scatter (FSC), representing size, against side scatter (SSC) representing granularity. Cytograms $2 \mathrm{~A}, 2 \mathrm{~B}$ and $2 \mathrm{C}$ plot count against propidium iodide emission (PI-A). A: Freshly purified tachyzoites with no temperature treatment; B: Tachyzoites incubated at $37^{\circ} \mathrm{C}$ for 1 hour; C: Tachyzoites incubated at $85^{\circ} \mathrm{C}$ for 20 minutes. The squares indicate the percentage of tachyzoites detected negatively (P2) and positively (P3) by propidium iodide. 
Semi-quantification of incubated tachyzoites by ELISA, $\beta$-galactosidase and real-time PCR

$N$. caninum tachyzoites detected by ELISA, $\beta$-galactosidase and real-time PCR exhibited a similar tendency. In the ELISA assay, the absorbance of tachyzoites incubated at $85^{\circ} \mathrm{C}$ and $37^{\circ} \mathrm{C}$ showed lower values than those of freshly purified ones. The three concentrations of tachyzoites exhibited a linear pattern with $\mathrm{r}^{2}$ of $0.94,0.98$ and 0.93 , respectively, for incubations at $85^{\circ} \mathrm{C}$ and $37^{\circ} \mathrm{C}$ and freshly purified tachyzoites (Figure $3 \mathrm{~A}$ ). The lacZ activity indicated the same decreasing pattern of invasive/adhesive tachyzoites when incubated at $37^{\circ} \mathrm{C}$ (the $\mathrm{r}^{2}$ of $37^{\circ} \mathrm{C}$-incubated and freshly purified tachyzoites were 0.95 and 0.96 , respectively, Figure $3 \mathrm{~B}$ ). After incubation at $85^{\circ} \mathrm{C}$, the detection of $\mathrm{LacZ}$ activity was not feasible because the enzyme $\beta$-galactosidase was denatured. Due to the high sensitivity of the real-time PCR assay, the number of tachyzoites employed in the invasion assay was 10 fold lower than for the ELISA and $\beta$-galactosidase assays, with $1 \times 10^{5}, 5 \times 10^{4}$ and $1 \times 10^{4}$ (Figure 3C). The $85^{\circ} \mathrm{C}$-incubated tachyzoites indicated an $\mathrm{r}^{2}$ of 0.87 with the three concentrations of tachyzoites, the incubation at $37^{\circ} \mathrm{C}$ yielded an $\mathrm{r}^{2}$ of 0.95 and the freshly purified tachyzoites an $r^{2}$ of 0.96 .

\section{Effects of temperature on the efficiency of tachyzoite invasion}

Two ratios were calculated to analyze the effects of different temperatures on the tachyzoites. First, a correlation between tachyzoites incubated at $37^{\circ} \mathrm{C}$ and the freshly purified cells was calculated (ratio of $37^{\circ} \mathrm{C} /$ fresh ${ }^{*} 100$ ), which represents the tachyzoites able to adhere to and/or invade host cells after a $37^{\circ} \mathrm{C}$ incubation. Secondly, the correlation between tachyzoites incubated at $85^{\circ} \mathrm{C}$ and $37^{\circ} \mathrm{C}$ was calculated (ratio of $85^{\circ} \mathrm{C} / 37^{\circ} \mathrm{C}^{*} 100$ ), which represents the tachyzoites able to adhere to host cells even after death.

The ELISA assay applied as an alternative method to measure invasion indicated a high correlation between tachyzoites incubated at $37^{\circ} \mathrm{C}$ and those that were freshly purified: $77.2 \%\left(1 \times 10^{6}\right.$ tachyzoites/well), 66.2\% $\left(5 \times 10^{5}\right)$ and $50.9 \%\left(1 \times 10^{5}\right)($ Fig. $4 \mathrm{~A})$. On the other hand, $32.2 \%\left(1 \times 10^{6}\right), 21.8 \%\left(5 \times 10^{5}\right)$ and $24.8 \%$ $\left(1 \times 10^{5}\right)$ of dead tachyzoites were still able to adhere (Figure $4 \mathrm{~A}$ ). The real-time PCR indicated adhesion after death at $85^{\circ} \mathrm{C}$, with the ratio of $85^{\circ} \mathrm{C} / 37^{\circ} \mathrm{C}$ decreasing to $39.9 \%\left(1 \times 10^{5}\right), 44.5 \%$ $\left(5 \times 10^{4}\right)$ and $27.0 \%\left(1 \times 10^{4}\right)($ Figure $4 \mathrm{C})$, while that of $37^{\circ} \mathrm{Cl}$ freshly purified tachyzoite was $92.7 \%\left(1 \times 10^{5}\right), 71.1 \%\left(5 \times 10^{4}\right)$ and $59.5 \%\left(1 \times 10^{5}\right)$ (Figure $\left.4 \mathrm{C}\right)$. The $\beta$-galactosidase method maintained the correlation between $37^{\circ} \mathrm{C} /$ freshly purified with $85.03 \%$ for $1 \times 10^{6}, 79.44 \%$ for $5 \times 10^{5}$ and $78.97 \%$ for $1 \times 10^{5}$ (Figure $4 \mathrm{~B}$ ), which was similar to that of ELISA and real-time PCR. Overall, there were no significant differences among the dilutions, except for tachyzoites at $1 \times 10^{5}$ and $1 \times 10^{6}$ with the correlation $37^{\circ} \mathrm{C} /$ freshly purified tachyzoites (Figure $4 \mathrm{~A}$ ).

\section{Discussion}

$N$. caninum direct or indirect detection in cell cultures and tissues is well established by traditional methods, such as IFAT
(YAKHCHALI et al., 2010), and highly specific methods such as real-time PCR (DEBACHE et al., 2010; GHALMI et al., 2008; NAGULESWARAN et al., 2003; PEREIRA et al., 2011). The three methods tested in this study for the detection of $N$. caninum invasion and/or adherence in cell culture showed a similar pattern, indicating that different methods may be complementary, since
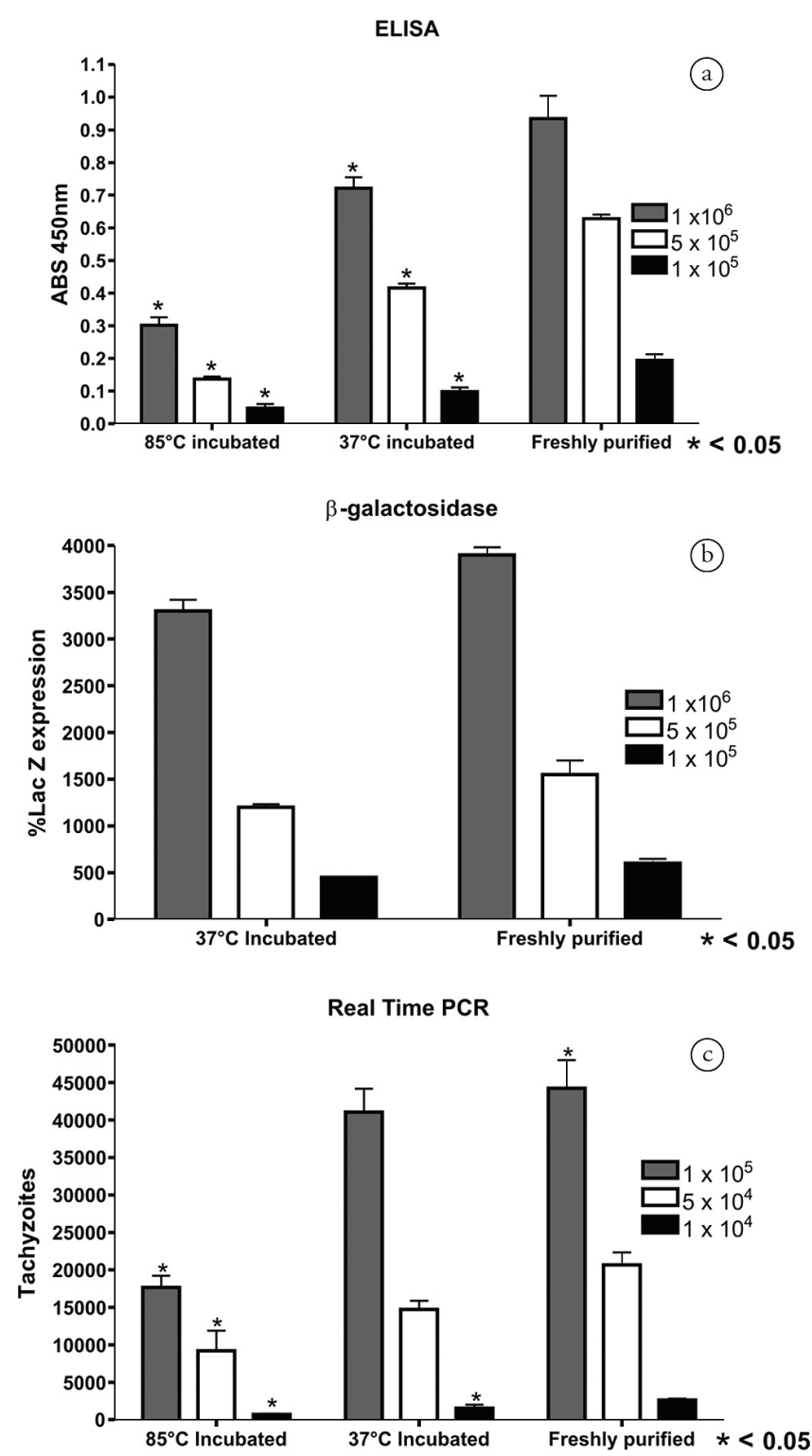

Figure 3. Detection of N. caninum incubated at $37^{\circ} \mathrm{C}, 85^{\circ} \mathrm{C}$ or freshly purified by ELISA, $\beta$-galactosidase and real-time PCR. The tachyzoites were diluted $1 \times 10^{6}, 5 \times 10^{5}$ and $1 \times 10^{5} /$ well for ELISA and $\beta$-galactosidase and $1 \times 10^{5}, 5 \times 10^{4}$ and $1 \times 10^{4}$ for real-time PCR and divided in three groups before invasion. After purification, one part was incubated at $37^{\circ} \mathrm{C}$ for $1 \mathrm{hr}$, the second part incubated at $85^{\circ} \mathrm{C}$ for $20 \mathrm{~min}$ and the third part was immediately allowed to invade Vero cells (freshly purified). A: ELISA; B: $\beta$-galactosidase; C: Real-time PCR. The detection was performed with antisera (ELISA), expression of LacZ gene in $N$. caninum transiently transfected with a LacZ plasmid ( $\beta$-galactosidase), or with $N$. caninum DNA measurement (real-time PCR). * represents significant difference < 0.05 in relation to the freshly purified group. 


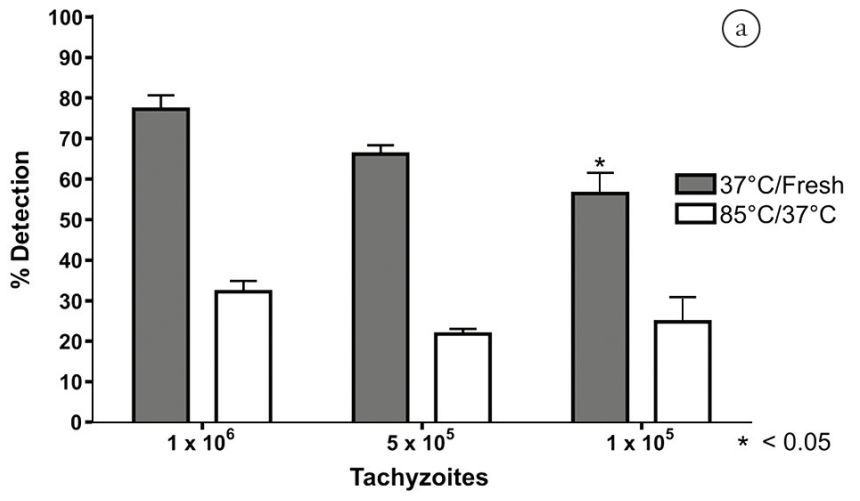

$\beta$-galactosidase

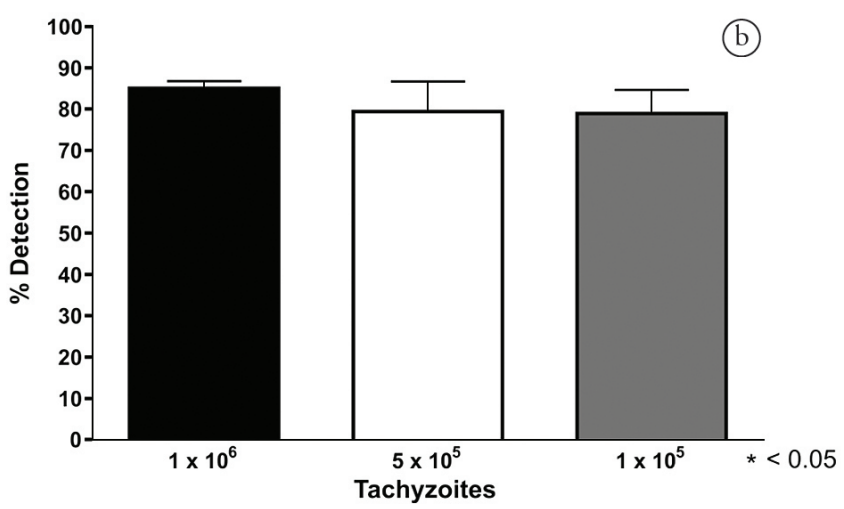

Real Time PCR

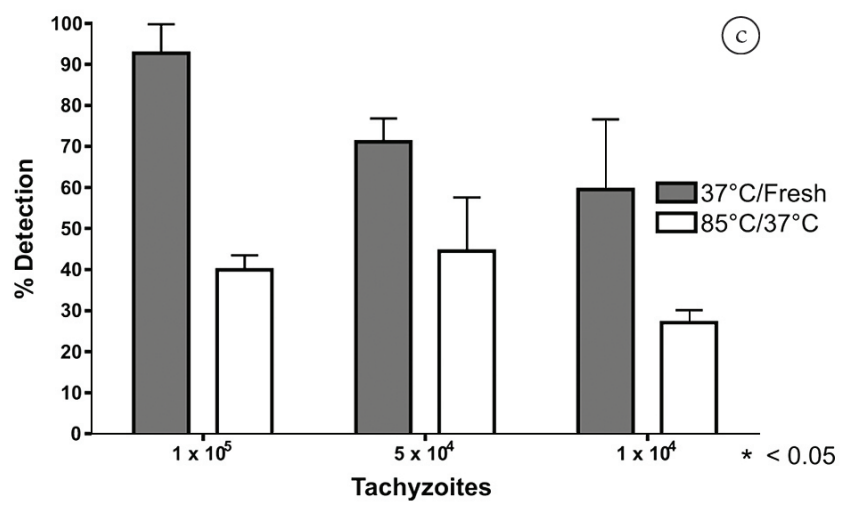

Figure 4. Decrease in adhesion/invasion of $N$. caninum after incubation at $37^{\circ} \mathrm{C}$ or $85^{\circ} \mathrm{C}$ by ELISA, $\beta$-galactosidase and real-time PCR. The correlations between $37^{\circ} \mathrm{C} /$ freshly purified and $85^{\circ} \mathrm{C} / 37^{\circ} \mathrm{C}$ incubated tachyzoite were calculated after detection by ELISA (A, anti-tachyzoite protein extract), and real-time PCR (C, primers Nc-5). For the $\beta$-galactosidase activity (\% lacZ expression), only the $37^{\circ} \mathrm{C} /$ fresh correlation was obtained because the enzyme was inactivated at $85^{\circ} \mathrm{C}$. Tachyzoites were incubated in three dilutions: $1 \times 10^{6}, 5 \times 10^{5}$ and $1 \times 10^{5} /$ well for ELISA and $\beta$-galactosidase and $1 \times 10^{5}, 5 \times 10^{4}$ and $1 \times 10^{4}$ for real-time PCR. A: ELISA; B: $\beta$-galactosidase; $C$ : Real-time PCR. *represents a significant difference $(<0.05)$.
ELISA, $\beta$-galactosidase and real-time PCR are based on different principles, i.e., antibodies, enzymatic reporter and genomic DNA, respectively. The number of tachyzoites per well applied in $\beta$-galactosidase and ELISA ranges from $10^{5}-10^{6}$, limiting evaluations to lower parasite loads; hence, real-time PCR may be the best choice. Thus, the first two methods are suitable for an initial evaluation of parasite invasion and real-time PCR participates as an unequivocal quantitative assay. The incubation of $N$. caninum or $T$. gondii at $37^{\circ} \mathrm{C}$ is a current way to determine the in vitro effects of drugs or sera on the invasion phenomenon (NAGULESWARAN et al., 2003; PEREIRA et al., 2011; SAWMYNADEN et al., 2008). Our results indicate that all these methods show losses of invasive/adhesive tachyzoites incubated at $37^{\circ} \mathrm{C}$; therefore, this is an important effect to take into account when designing assays that require long incubation times.

On the other hand, $N$. caninum maintains a basal level of adhesion even after incubation at $85^{\circ} \mathrm{C}$, which is a temperature that leads to the death of $98.5 \%$ of the tachyzoites, according to propidium iodide positivity. Such a high temperature probably denatures many of the tachyzoite's surface proteins; however, a basal adhesion capacity is detected and may indicate mechanisms of parasite/host affinity independent of the parasite's viability. Propidium iodide is only internalized when the membrane is disrupted; conversely, membrane integrity is necessary to enable the initial tachyzoite invasion process (CARRUTHERS; BOOTHROYD, 2007).

A semi-quantitative method for the detection of $N$. caninum based on ELISA after invasion assays in cell culture integrates characteristics of histochemistry (fixation, permeabilization) and immunology (ELISA, indirect detection of antibodies by colorimetric peroxidase reaction), offering an additional fast, low cost method to determine the influence of substances on the in vitro invasion process. Albeit highly specific and sensitive, realtime PCR requires high quality inputs, such as primers, probes, thermal cyclers with suitable detectors, software and an optimal standardization (BELL; RANFORD-CARTWRIGHT, 2002). On the other hand, it allows for quantitation and requires lower cell concentrations in the assays. The high specificity and sensitivity of real-time PCR led to higher ratios $\left(37^{\circ} \mathrm{C} /\right.$ fresh and $\left.85^{\circ} \mathrm{C} / 37^{\circ} \mathrm{C}\right)$, probably due to the higher tachyzoite detection capacity of this technique compared to that of ELISA and $\beta$-galactosidase. The $\beta$-galactosidase method is less laborious to standardize; however, it requires tachyzoites expressing $\beta$-galactosidase (HOWE et al., 1997, the expression of LacZ gene was controlled by $T$. gondii promoters), which is absent in wild-type Nc-1 tachyzoites. Although extremely well developed in $T$. gondii, the expression of heterologous genes in $N$. caninum is not an ordinary technique.

This newly described ELISA assay requires an antiserum against $N$. caninum tachyzoite protein extract. Its specificity/sensitivity led to a detection cut-off of $1 \times 10^{5}$ tachyzoites per well, which was verified by the differences observed between concentrations of $1 \times 10^{5}$ and $1 \times 10^{6}$ tachyzoites incubated at $37^{\circ} \mathrm{C}$ (Figure $\left.4 \mathrm{~A}\right)$, with a significant difference probably due to the small number of tachyzoites required by this method. The incubations indicated that the number of parasites is a limiting factor for optimal detection by ELISA, although a similar condition was found for $\beta$-galactosidase and only real-time PCR presented higher sensitivity. 
The polyclonal sera against the tachyzoites extract obtained from urea $8 \mathrm{M}$ buffer raises a wide range of antibodies, which offers a robust absorbance in $N$. caninum detection. A significant number of antibodies recognize only $N$. caninum proteins, and for $1 \times 10^{6}$ tachyzoites, ELISA is as adequate as beta-gal or real time assays, which validate the method. The difference between $N$. caninum and Vero cell absorbance is 0.720 in parasites incubated at $37^{\circ} \mathrm{C}$ for 1 hour, a suitable range for invasion evaluations (Figure 3A). The ELISA method described here appears to be a low cost route to evaluate the invasion process of $N$. caninum, a simple and fast method for laboratories whose routine lacks a structure for the application of molecular tools. In addition, $\beta$-galactosidase activity showed the applicability of $N$. caninum promoters for heterologous expression. The ELISA and the $\beta$-galactosidase assays exhibited a pattern similar to that of the highly specific and sensitive real-time PCR, indicating the effects of incubation and temperature on the viability and invasion process of $N$. caninum. Overall, this ELISA method is expected to support the design of more adequate assays for screening agonists and antagonists that are active in the invasion process.

\section{Acknowledgements}

The authors would like to thank Fabiana Rosseto de Morais (FCFRP-USP) for her technical assistance with the flow cytometry and Intervet International for supplying the plasmid with tetO and LacZ sequence (pRPS13LacZ, van POPPEL et al., 2006).

The authors gratefully acknowledge the Brazilian research funding agencies CAPES (Federal Agency for the Support and Improvement of Higher Education) and FAPESP (São Paulo Research Foundation) for the award of PhD fellowships to Pereira (CAPES and FAPESP 2009/07713-7), and CNPq (National Council for Scientific and Technological Development) and FAPESP for awarding research grants (FAPESP, 2005-3/53785-9; CNPq 478767/2007-2).

\section{References}

Bell A, Ranford-Cartwright L. Real-time quantitative PCR in parasitology. Trends Parasitol 2002; 18(8): 337-342. http://dx.doi. org/10.1016/S1471-4922(02)02331-0

Bjorkman C, Lunden A. Application of iscom antigen preparations in ELISAs for diagnosis of Neospora and Toxoplasma infections. Int J Parasitol 1998; 28(1): 187-193. http://dx.doi.org/10.1016/S00207519(97)00174-4

Carruthers V, Boothroyd JC. Pulling together: an integrated model of Toxoplasma cell invasion. Curr Opin Microbiol 2007; 10(1): 83-89. PMid:16837236. http://dx.doi.org/10.1016/j.mib.2006.06.017

Cesbron-Delauw MF, Gendrin C, Travier L, Ruffiot P, Mercier C. Apicomplexa in mammalian cells: trafficking to the parasitophorous vacuole. Traffic 2008; 9(5): 657-664. PMid:18315533. http://dx.doi. org/10.1111/j.1600-0854.2008.00728.x

Collantes-Fernandez E, Zaballos A, Alvarez-Garcia G, OrtegaMora LM. Quantitative detection of Neospora caninum in bovine aborted fetuses and experimentally infected mice by real-time
PCR. J Clin Microbiol 2002; 40(4): 1194-1198. PMid:11923330 PMCid:PMC140374. http://dx.doi.org/10.1128/JCM.40.4.11941198.2002

Corbellini LG, Pescador CA, Frantz F, Wunder E, Steffen D, Smith $\mathrm{DR}$, et al. Diagnostic survey of bovine abortion with special reference to Neospora caninum infection: importance, repeated abortion and concurrent infection in aborted fetuses in Southern Brazil. Vet J2006; 172(1): 114-120. PMid:16772136. http://dx.doi.org/10.1016/j. tvjl.2005.03.006

D’Angelo JG, Bordon C, Posner GH, Yolken R, Jones-Brando L. Artemisinin derivatives inhibit Toxoplasma gondii in vitro at multiple steps in the lytic cycle. J Antimicrob Chemother 2009; 63(1): 146-150. PMid:18988681 PMCid:PMC2639242. http://dx.doi.org/10.1093/ $\mathrm{jac} / \mathrm{dkn} 451$

Darwich L, Cabezon O, Echeverria I, Pabon M, Marco I, MolinaLopez R, etal. Presence of Toxoplasma gondii and Neospora caninum DNA in the brain of wild birds. Vet Parasitol 2012; 183(3-4): 377-381. PMid:21831525. http://dx.doi.org/10.1016/j.vetpar.2011.07.024

Das S, Shevade S, LaCount DJ, Jarori GK. Plasmodium falciparum enolase complements yeast enolase functions and associates with the parasite food vacuole. Mol Biochem Parasitol 2011; 179(1): 8-17. PMid:21600245 PMCid:PMC3353271. http://dx.doi.org/10.1016/j. molbiopara.2011.05.001

Debache K, Guionaud C, Alaeddine F, Hemphill A. Intraperitoneal and intra-nasal vaccination of mice with three distinct recombinant Neospora caninum antigens results in differential effects with regard to protection against experimental challenge with Neospora caninum tachyzoites. Parasitology 2010; 137(2): 229-240. PMid:19835644. http://dx.doi. org/10.1017/S0031182009991259

Dubey JP, Hattel AL, Lindsay DS, Topper MJ. Neonatal Neospora caninum infection in dogs: isolation of the causative agent and experimental transmission. J Am Vet Med Assoc 1988; 193(10): 12591263. PMid:3144521.

Esperandim VR, Da Silva Ferreira D, Toldo MP, Saraiva J, Augusto MB, De Albuquerque S. New method for quantification of Trypanosoma cruzi in animal's tissue in the chronic phase of experimental Chagas' disease. Parasitol Res 2010; 106(6): 1471-1473. PMid:20177904. http://dx.doi. org/10.1007/s00436-010-1780-7

Ghalmi F, China B, Kaidi R, Daube G, Losson B. Detection of Neospora caninum in dog organs using real time PCR systems. Vet Parasitol 2008; 155(1-2): 161-167. PMid:18502585. http://dx.doi. org/10.1016/j.vetpar.2008.04.007

Howe DK, Mercier C, Messina M, Sibley LD. Expression of Toxoplasma gondii genes in the closely-related apicomplexan parasite Neospora caninum. Mol Biochem Parasitol 1997; 86(1): 29-36. http://dx.doi. org/10.1016/S0166-6851(96)02838-1

Hughes JM, Williams RH, Morley EK, Cook DA, Terry RS, Murphy RG, et al. The prevalence of Neospora caninum and co-infection with Toxoplasma gondii by PCR analysis in naturally occurring mammal populations. Parasitology 2006; 132(Pt1): 29-36. PMid:16393351.

Jenkins M, Baszler T, Bjorkman C, Schares G, Williams D. Diagnosis and seroepidemiology of Neospora caninum-associated bovine abortion. Int J Parasitol 2002; 32(5): 631-636. http://dx.doi.org/10.1016/S00207519(01)00363-0

Lovett JL, Howe DK, Sibley LD. Molecular characterization of a thrombospondin-related anonymous protein homologue in Neospora 
caninum. Mol Biochem Parasitol 2000; 107(1): 33-43. http://dx.doi. org/10.1016/S0166-6851(99)00228-5

Meissner M, Brecht S, Bujard H, Soldati D. Modulation of myosin A expression by a newly established tetracycline repressor-based inducible system in Toxoplasma gondii. Nucleic Acids Res 2001; 29(22): E115. PMid:11713335 PMCid:PMC92585. http://dx.doi.org/10.1093/ nar/29.22.e115

Meissner M, Schluter D, Soldati D. Role of Toxoplasma gondii myosin A in powering parasite gliding and host cell invasion. Science 2002; 298(5594): 837-840. PMid:12399593. http://dx.doi. org/10.1126/science. 1074553

Morahan BJ, Wang L, Coppel RL. No TRAP, no invasion. Trends Parasitol 2009; 25(2): 77-84. PMid:19101208. http://dx.doi. org/10.1016/j.pt.2008.11.004

Moreno B, Collantes-Fernandez E, Villa A, Navarro A, RegidorCerrillo J, Ortega-Mora LM. Occurrence of Neospora caninum and Toxoplasma gondii infections in ovine and caprine abortions. Vet Parasitol 2012; 187(1-2): 312-318. PMid:22260901. http://dx.doi. org/10.1016/j.vetpar.2011.12.034

Naguleswaran A, Muller N, Hemphill A. Neospora caninum and Toxoplasma gondii: a novel adhesion/invasion assay reveals distinct differences in tachyzoite-host cell interactions. Exp Parasitol 2003; 104(3-4): 149-158. http://dx.doi.org/10.1016/S0014-4894(03)00137-1
Pereira LM, Candido-Silva JA, De Vries E, Yatsuda AP. A new thrombospondin-related anonymous protein homologue in Neospora caninum (NcMIC2-like1). Parasitology 2011; 138(3): 287-297. PMid:20880420. http://dx.doi.org/10.1017/S0031182010001290

Reichel MP, Alejandra Ayanegui-Alcérreca M, Gondim LF, Ellis JT. What is the global economic impact of Neospora caninum in cattle - the billion dollar question. Int J Parasitol 2013; 43(2):133-142. PMid:23246675. http://dx.doi.org/10.1016/j.ijpara.2012.10.022

Sawmynaden K, Saouros S, Friedrich N, Marchant J, Simpson P, Bleijlevens B, et al. Structural insights into microneme protein assembly reveal a new mode of EGF domain recognition. EMBO Rep 2008; 9(11): 1149-1155. PMid:18818666 PMCid:PMC2581848. http://dx.doi.org/10.1038/embor.2008.179

Van Poppel NF, Welagen J, Duisters RF, Vermeulen AN, Schaap D. Tight control of transcription in Toxoplasma gondii using an alternative tet repressor. Int J Parasitol 2006; 36(4): 443-452. PMid:16516216. http://dx.doi.org/10.1016/j.ijpara.2006.01.005

Vavrova L, Muchova K, Barak I. Comparison of different Bacillus subtilis expression systems. Res Microbiol 2010; 161(9): 791-797. PMid:20863884. http://dx.doi.org/10.1016/j.resmic.2010.09.004

Yakhchali M, Javadi S, Morshedi A. Prevalence of antibodies to Neospora caninum in stray dogs of Urmia, Iran. Parasitol Res 2010; 106(6): 14551458. PMid:20379836. http://dx.doi.org/10.1007/s00436-010-1824-z 